\title{
Achillotenotomiák hosszú távú eredményei spasticus cerebralis paresisben szenvedő betegekben
}

\author{
Kérő Gábor dr. - Frigyesi László dr. - Szabó Tamás dr. \\ Than Péter dr. - Vermes Csaba dr.
}

Pécsi Tudományegyetem, Általános Orvostudományi Kar, Klinikai Központ, Ortopédiai Klinika, Pécs

\begin{abstract}
Bevezetés: A spasticus cerebralis paresisben szenvedő betegek kezelésének egyik legfontosabb faktora az állást és a járásképességet befolyásoló equinuscontractura műtéti megoldása. Klinikánkon nyílt Z-achillotenotomia mellett az Achilles-ín percutan tripla hemisectióját végezzük rutinszerúen.

Célkitüzés: Munkánk célja volt, hogy a klinikánkon spasticus cerebralis paresises betegeken végzett achillotenotomiák hosszú távú eredményeit elemezzük, keressük a fő komplikációk prediszponáló faktorait, illetve összehasonlítsuk a nyílt és percutan végzett mütétek hosszú távú kimenetelét.

Módszer: Klinikánkon 1990 és 2006 között 211 betegnél, összesen 347 esetben végeztük el az Achilles-ín megnyújtását. 261 esetben percutan, 86 esetben pedig nyílt feltárásból történtek a mútétek. Munkánk során a betegek átlagosan 15 éves utánkövetésének retrospektív analízisét végeztük el. Az egyes esetek hosszú távú eredményeit a mútéti életkor, az alapbetegség topográfiai megjelenési formája és a cerebralis paresis súlyossága alapján elemeztük. A betegek járóképességét, illetve annak változását a kezelés során az úgynevezett 'Physician Rating Scale' pontrendszer szerint értékeltük.

Eredmények: Recidív equinuscontractura miatt 74 esetben végeztünk reachillotenotomiát $(21,3 \%) ; 14$ esetben (4\%) a reachillotenotomiát második alkalommal is el kellett végezni. Túlkorrekcióval 12 esetben $(3,5 \%)$ találkoztunk. Fiatalabb életkorban (<7 év) operált, illetve súlyosabb paresis (GMFCS II-III.) esetén bizonyult a recidívaráta a legmagasabbnak ( 26\%). A recidíva 9 és 14 éves kor között jelentős halmozódást mutatott.

Következtetés: A mútétet követő legfontosabb komplikáció a recidíva volt. Recidíva a legnagyobb arányban a fiatalabb korban operált, az alapbetegség súlyosabb formájában szenvedő betegeknél jelentkezett. Megfigyeltük, hogy a recidíva szoros összefüggést mutat a testnövekedéssel, illetve halmozódást mutat serdülőkorban.
\end{abstract}

Orv Hetil. 2020; 161(8): 306-312.

Kulcsszavak: achillotenotomia, spasticus cerebralis paresis, percutan tripla hemisectio

\section{Long-term follow-up of achillotenotomy in patients with cerebral palsy}

Introduction: The surgical solution of equinus deformity is one of the most important factors in the treatment of patients with cerebral palsy. We perform open $\mathrm{Z}$ achillotenotomy and percutaneus triple hemisection routinely in our department.

Aim: The goal of our work was to analyze the long-term results of achillotenotomies in patients with cerebral palsy, to look for predisposing factors of major complications, and to compare the results of the performed operative methods.

Method: Between 1990 and 2006, we performed 347 surgical Achilles tendon lengthenings. In 261 cases, the operations were performed percutaneusly, and in 86 cases we performed open $\mathrm{Z}$ achillotenotomy. The average follow-up time was 15 years. The long-term outcomes were analyzed based on the age at surgery, the topographic appearance and the severity of cerebral palsy. Analysis regarding functional outcome was based on the widely known Physician Rating Scale system.

Results: Due to recurrent equinus deformity, re-achillotenotomy was performed in 74 cases $(21.3 \%)$, and in 14 cases $(4 \%)$ the re-achillotenotomy needed to be performed a second time. We encountered overcorrection and calcaneus deformity in 12 cases $(3.5 \%)$. Recurrence rate was higher in patients operated at a younger age $(<7$ years $)$ and in patients with a more severe cerebral palsy (GMFCS II-III, 26\%). Recurrence showed accumulation in patients 9-14 years old. 
Conclusion: The major complication we encountered was recurrence of the equinus deformity. The majority of relapses occured in patients who were operated at a younger age and suffered from a more severe form of cerebral palsy. We observed that recurrence showed an association with growth and accumulated in aldolescence.

Keywords: achillotenotomy, spastic cerebral palsy, percutaneus triple hemisection

Kérő G, Frigyesi L, Szabó T, Than P, Vermes Cs. [Long-term follow-up of achillotenotomy in patients with cerebral palsy]. Orv Hetil. 2020; 161(8): 306-312.

(Beérkezett: 2019. október 20.; elfogadva: 2019. november 17.)

\section{Rövidítések}

GMFCS $=($ Gross Motor Function Classification System $)$ a betegek alapbetegségének súlyosságát leíró rendszer; PRS = (Physician Rating Scale) orvosi értékelési skála

Napjainkban a komplikált születésen átesett vagy egyéb okból perinatalis központi idegrendszeri károsodást szenvedett gyermekek túlélése - a folyamatosan fejlődő orvostechnikai eszközöknek hála - sokat javult.

$\mathrm{Az}$ ilyen változó mértékú és megjelenésú központi idegrendszeri károsodás a szellemi fejlődés elmaradásához, valamint a mozgásszervekben - többségében spasticus izomgyengeséghez, bénulásokhoz és contracturák létrejöttéhez vezethet.

Az így kialakuló kórkép az úgynevezett infantilis cerebralis paresis (morbus Little), mely prae- vagy perinatalis agyi károsodás következtében kialakuló pszichoszenzomotoros zavar. Gyakorisága körülbelül 0,2\% [1]. Tüneti megjelenését alapvetően az idegrendszeri károsodás ideje és lokalizációja határozza meg. Tünetei között találkozhatunk spasticitassal, dyskinesissel, ataxiával, de akár tremorral és atoniával is, illetve ezek különböző dominanciájú kombinációival. A leggyakoribb a spasticus forma, mely az összes eset körülbelül 75\%-át teszi ki [1].

Ortopédiai szempontból a spasticus csoportnak van a legnagyobb jelentősége, ugyanis ebben a csoportban van a leginkább lehetőségünk javítani a betegek állapotán. A spasticus klinikopatológiai formánál fóleg hajlító oldali spasticus contracturákat láthatunk, clonusos, fokozott és patológiás ínreflexek mellett, s ezen contracturák oldása a fó feladatunk. Az alsó végtagon a csípőízületben jellegzetesen addukció, flexió és berotáció, a térdízületben flexió, míg a felsó ugróízületben úgynevezett equinuscontracturák dominálnak. Előfordulásukat tekintve a leggyakoribb és az állás- és járásképességet a leginkább befolyásoló deformitás a felső ugróízületet érintő equinustartás. Az említett alsó végtagi deformitások jellegzetes járásmintázatot idéznek elő, jellemző az ollózó járásminta, a betegek a sarkukat járás közben képtelenek lerakni, lábujjhegyen járnak.

A kezelés alapja a konzervatív terápia, melynek része a deformált, contracturás ízületek gyógytornája, a spasmus csökkentése izomlazító gyógyszerekkel, illetve botulinumtoxin segítségével, speciális ortézisek alkalmazása,

olykor gipszredressio, továbbá a szellemi és testi fejlődést szolgáló konduktív pedagógia erre specializálódott intézetekben [2-6].

A konzervatív kezelést sok esetben mútéti kezeléssel kell kiegészíteni: ez eme kórkép esetében az említett contracturákat fenntartó spasticus izmok inainak tenotomiáját jelenti, mely ezáltal biztosítja a zárt kinematikus láncot képező ízületek megfelelő mozgástartományát, illetve így a végtag megfelelő tengelyállását, javítva ezzel az állás- és járásképességet.

A felső ugróízületi equinuscontractura megoldására számos mútéti technika áll rendelkezésre. A spasticus és rövidült plantarflexor izomzaton végezhetjük a nyújtást az izomhas, az izom-ín átmenet és az Achilles-inas részen. A mútéti megoldást mindig egyénre szabottan kell kiválasztani annak függvényében, hogy a plantarflexorok közül mely izmok tartják fenn dominánsan az equinustartást.

Klinikánkon a deformitás mútéti megoldására döntő többségében nyílt Z-tenotomiát, illetve a Hatt által 1947-ben leírt percutan tripla hemisectiót végezzük rutinszerúen (1. ábra). Az Achilles-ín nyújtását célzó mûtéti megoldásoknak széles körü az irodalma, a tanulmányok azonban döntően kisebb esetszámúak, és rövid vagy középtávú utánkövetést elemeznek. Szükség van nagy esetszámú, hosszú távú vizsgálatokra, melvek alapján meghatározhatjuk, hogy milyen eredményei vannak az operatív kezelésnek, milyen gyakori a recidíva vagy a túlkorrekció, melyek az Achilles-ín-nyújtó mútétek fó komplikációi. Szükséges továbbá megvizsgálni az egyes fő komplikációkhoz vezető prediszponáló faktorokat,

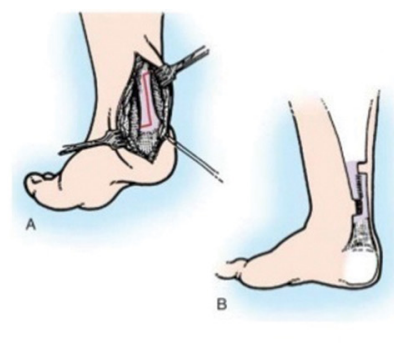

Nyílt Z-tenotomia

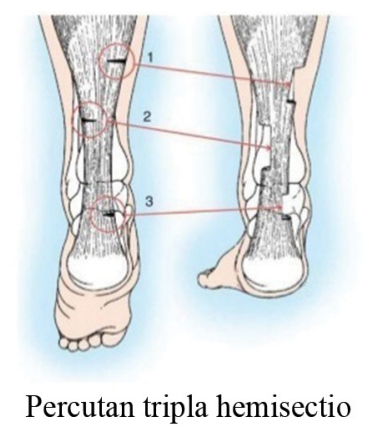

1. ábra | A klinikánkon alkalmazott mútéti eljárások 
melyek segítségével egyénre szabott utánkövetési stratégiát dolgozhatunk ki.

Tanulmányunk célja volt, hogy a klinikánkon gondozott, már több mint 10 éves utánkövetéssel rendelkező, spasticus cerebralis paresisben szenvedő és az Achilles-ín operatív nyújtásán átesett betegek eseteit retrospektíven áttekintsük. Vizsgálatunk keretében áttekintettük az utánkövetés során észlelt komplikációkat, kerestük azok prediszponáló faktorait, illetve vizsgáltuk a komplikációk időbeli megoszlását.

\section{Módszer}

1990 és 2006 között klinikánkon 319, spasticus cerebralis paresisben szenvedő betegnél végeztünk Achilles-ínnyújtást. Ezen páciensek közül 211-et sikerült bevonni a vizsgálatba, akiknél rendelkeztünk részletes, hosszú távú utánkövetéssel és megfelelő dokumentációval.

A betegeket a neurológiai sérülés, illetve a tünetek topográfiai megjelenése szerint 3 csoportra osztottuk: hemiparesises, di-/paraparesises és tetraparesises betegek. Emellett a páciensek eseteit az alapbetegség súlyosságát leíró, úgynevezett Gross Motor Function Classification System (a továbbiakban: GMFCS) [7] alapján is elemeztük.

A járóképességet, a járásképet és a felső ugróízület funkcióját a vizsgálati időben rutinszerűen a 'Physician Rating Scale' pontrendszer (a továbbiakban: PRS) alapján vizsgáltuk [5]. A PRS-érték változását statisztikai szempontból az SPSS-program (IBM Corporation, Armonk, NY, Amerikai Egyesült Államok) segítségével kétmintás előjelpróbával elemeztük $(\alpha=0,05)$.
1. táblázat $\mid$ A vizsgált betegcsoport jellemzői a vizsgálat fóbb szempontjai szerint

\begin{tabular}{ll}
\hline GMFCS & - GMFCS II.: $88(43,6 \%)$ \\
(Gross Motor Function & - GMFCS III.: $83(47,3 \%)$ \\
Classification System) & - GMFCS IV.: $40(9 \%)$ \\
\hline Topográfia & - Hemiplegia: $69(41,8 \%)$ \\
& - Di-/Paraplegia: $83(36,4 \%)$ \\
& - Tetraplegia: $59(21,8 \%)$ \\
\hline Calcaneus tengelyállás & - Varus: $45(12,9 \%)$ \\
& - Valgus: $208(59,9 \%)$ \\
& - Neutralis: $94(27,1 \%)$ \\
\hline Átlagéletkor & 5,8 év $(2,8-15,1$ év $)$ \\
\hline Átlagos utánkövetési idő & 15,1 év $(10,3-26,3$ év $)$ \\
\hline
\end{tabular}

GMFCS = a betegek alapbetegségének súlyosságát leíró rendszer

Az említett 211 betegnél összesen 347 esetben végeztünk Achilles-ín-nyújtó mútétet, 86 esetben nyílt Z-tenotomiát és 261 esetben percutan tripla hemisectiót. Az átlagos utánkövetési idő 15,1 év volt (10,3-26,3 év). $\mathrm{Az}$ átlagéletkor mútétkor 5,8 év (2,8-15,1 év) volt. A vizsgálatban 93 lány és 118 fiú szerepelt (1. táblázat).

\section{Eredmények}

A klinikánkon alkalmazott két mútéti megoldás gyakoriságát illetően azt találtuk, hogy a percutan, kisebb invazivitású mütéti eljárás az évek során egyre inkább előtérbe került, kihasználandó annak perioperatív elónyeit (2. ábra). A perioperatív konzervatív kezelési mód, az immobilizáció és a gipszrögzítés hossza a két mütéti

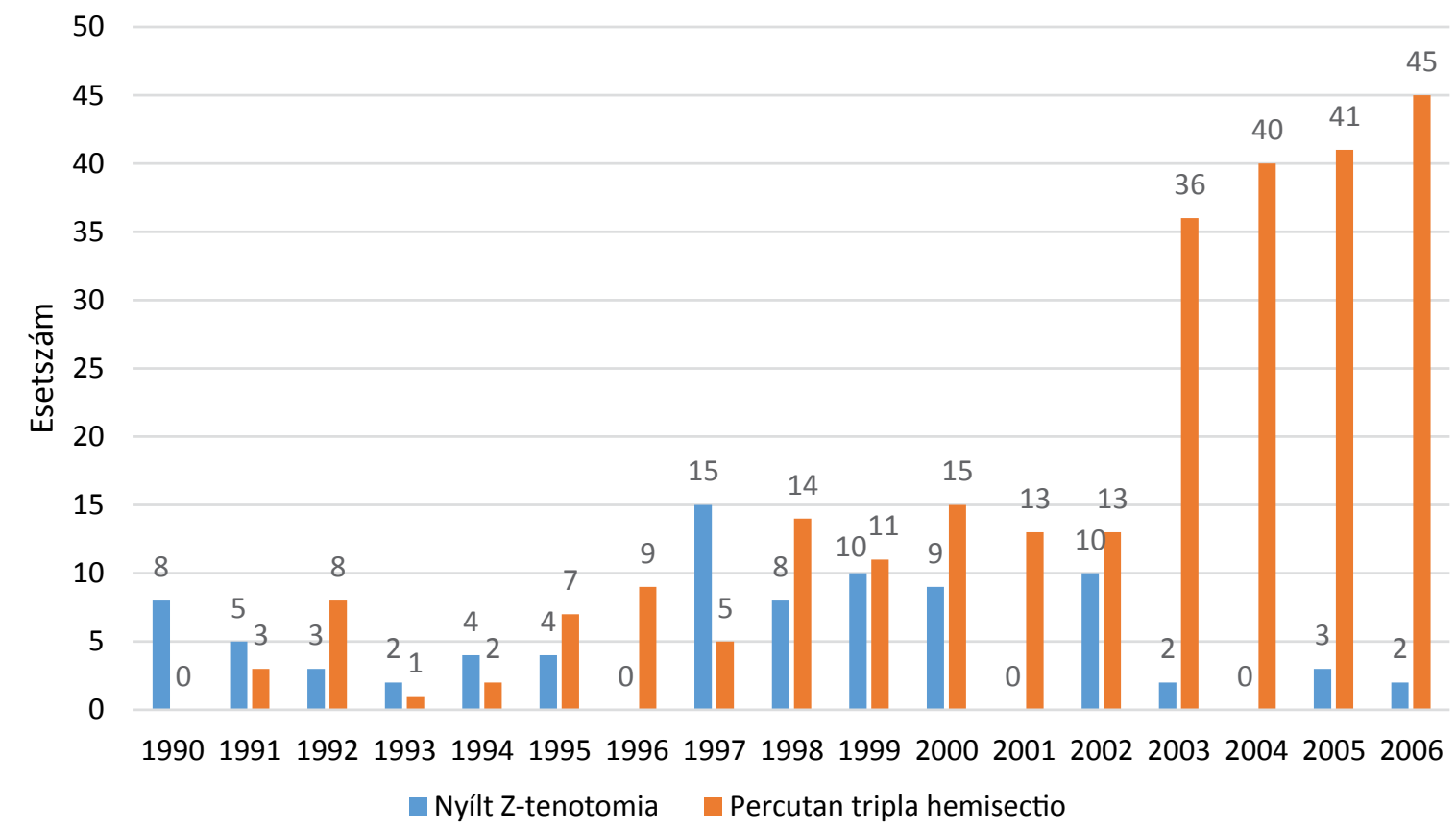

2. ábra | A vizsgált mútéti típusok alkalmazási aránya a vizsgálati időszak egyes éveiben 
Funkcionális eredmények a PRS (Physician Rating Scale) alapján

\begin{tabular}{lcclcc}
\hline PRS & $\begin{array}{c}\text { Pre- } \\
\text { opera- } \\
\text { tív }\end{array}$ & $\begin{array}{c}\text { Poszt- } \\
\text { operatív } \\
(0,5-1 \\
\text { éves } \\
\text { kontroll })\end{array}$ & Változás & $\begin{array}{c}\text { Az } \\
\text { után- } \\
\text { követés } \\
\text { vége }\end{array}$ & Változás \\
\hline $\begin{array}{l}\text { Alsó végtagi flexiós } \\
\text { contracturák } \\
\text { („crouch”) }\end{array}$ & 1,75 & 2,64 & $\mathrm{p}<0,05$ & 2,58 & $\mathrm{p}>0,05$ \\
\hline Genu recurvatum & 1,57 & 1,63 & $\mathrm{p}>0,05$ & 1,63 & $\mathrm{p}>0,05$ \\
\hline Saroktámasz & 1,11 & 3,24 & $\mathrm{p}<0,05$ & 3,22 & $\mathrm{p}>0,05$ \\
\hline Változás & - & 0,99 & - & $-0,06$ & - \\
\hline Összpontszám & 4,43 & 8,45 & $\mathrm{p}<0,05$ & 7,50 & $\mathrm{p}<0,05$ \\
\hline
\end{tabular}

PRS $=$ orvosi értékelési skála

megoldásnál nem különbözött (4-6 hétig gipszrögzítés, az első 10-14 napon tehermentesített mobilizáció, majd mobilizáció teljes terheléssel, gipszben). Lényeges különbség volt azonban a hospitalizációs idő, a hegképződés és a sebgyógyulási zavar tekintetében. Az átlagos hospitalizációs idő a percutan mútéten átesett betegeknél 4,8 nap, míg a nyílt mütéten átesetteknél 7,6 nap volt. Sebgyógyulási zavar 7 esetben lépett fel, minden esetben nyílt Z-tenotomiát követően, melyek gondos konzervatív sebkezelés mellett, mütéti beavatkozás nélkül gyógyultak. Jelentékeny hegképződés, hegfájdalom és diszkomfort miatt 5 esetben kényszerültünk hegkimetszés céljából ismételt műtétre. A betegek előzőleg minden esetben nyílt Z-tenotomián estek át, az említett komplikáció nem érintette a percutan mútéten átesett pácienseket. Achilles-ín-rupturát, ér-, illetve idegképletsérülést nem észleltünk.

Az elvégzett mütéteket követően minden esetben jelentős javulást észleltünk a preoperatív állapothoz képest a betegek álló- és járóképességében, valamint a láb dorsalflexiós mozgástartományában. A preoperatívan észlelt PRS-értékek a mütétet követően minden esetben szignifikáns emelkedést mutattak. A betegek sokéves utánkövetése során ezek az értékek az alkalmazott konzervatív kezelések mellett enyhe, statisztikailag nem szignifikáns csökkenést mutattak azokban az esetekben is, amelyekben mütétet igénylő recidíva nem lépett fel. Az összes esetet tekintve tehát az enyhe csökkenés dominált a PRS-értékeket tekintve az utánkövetés végéig (2. táblázat).

Összességében az utánkövetés során 74 esetben $(21,3 \%)$ láttunk recidívát, illetve 14 esetben $(4 \%)$ végeztünk második alkalommal is ismételt recidíva miatt reachillotenotomiát. Túlkorrekciót 12 esetben $(3,5 \%)$ észleltünk.

Megvizsgáltuk a recidíva előfordulási gyakoriságát az alapbetegség egyes topográfiai megjelenési formáiban is. 16 esetben $(23,9 \%)$ észleltünk recidívát a hemipareticus, 40 esetben $(24,1 \%)$ a parapareticus, míg 18 esetben $(15,8 \%)$ a tetrapareticus betegeknél (3. ábra).

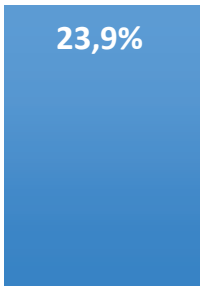

Hemiparesis

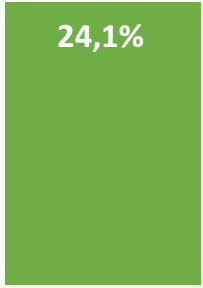

Di-/paraparesis

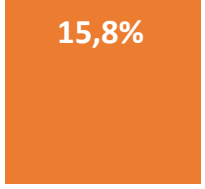

Tetraparesis
3. ábra $\quad$ A recidívaráta az alapbetegség topográfiai megjelenési formáinak megfelelően

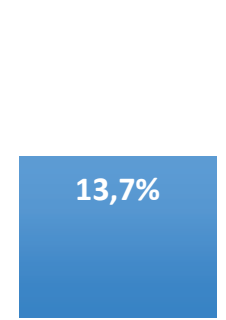

GMFCS II.

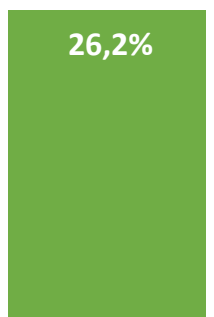

GMFCS III.

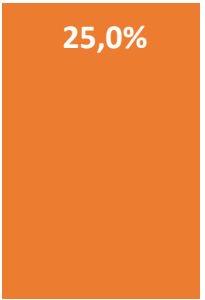

GMFCS IV. \begin{tabular}{l|l} 
4. ábra & $\begin{array}{l}\text { A recidívaráta az alapbetegség súlyosságának megfelelően } \\
\text { GMFCS }=\text { a betegek alapbetegségének súlyosságát leíró rend- } \\
\text { szer }\end{array}$
\end{tabular}

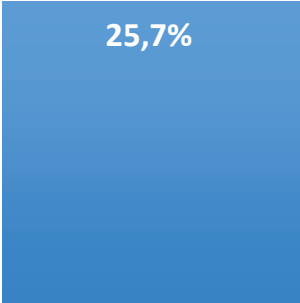

$<7$ év

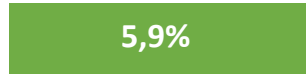

$>7$ év
5. ábra $\quad$ A recidívaráta a mútéti életkornak megfelelően

Áttekintve a recidíva gyakoriságát, az alapbetegség súlyosságát jellemző GMFCS-stádiumokban azt találtuk, hogy a II-es stádiumú betegeknél 18 esetben (13,7\%), a III-as stádiumban 38 esetben (26,2\%), míg a IV-es stádiumban 18 esetben $(25,0 \%)$ jelentkezett ismételten reoperációt igénylő equinusdeformitás (4. ábra).

Az életkor és a recidíva összefüggésének vizsgálatakor az találtuk, hogy 7 évnél idősebb életkorban végezve az első mútétet a recidívaráta 5,9\% (5 eset) volt, míg 7 évnél fiatalabb életkorban végezve az első beavatkozást a recidíva előfordulási aránya lényegesen magasabbnak, 25,7\%-nak (69 eset) bizonyult (5. ábra).

Vizsgáltuk, hogy a recidíva melyik életkorban jelentkezik a legnagyobb arányban. Megfigyeltük, hogy a recidíva a pubertáskorban halmozódást mutat. 10-14 éves korú betegeknél végeztünk a legnagyobb számban ( 58 eset) reachillotenotomiát, míg az említett intervallum alatt, illetve felett csak egy-egy esetben kényszerültünk ismételt mútétre (6. ábra). 


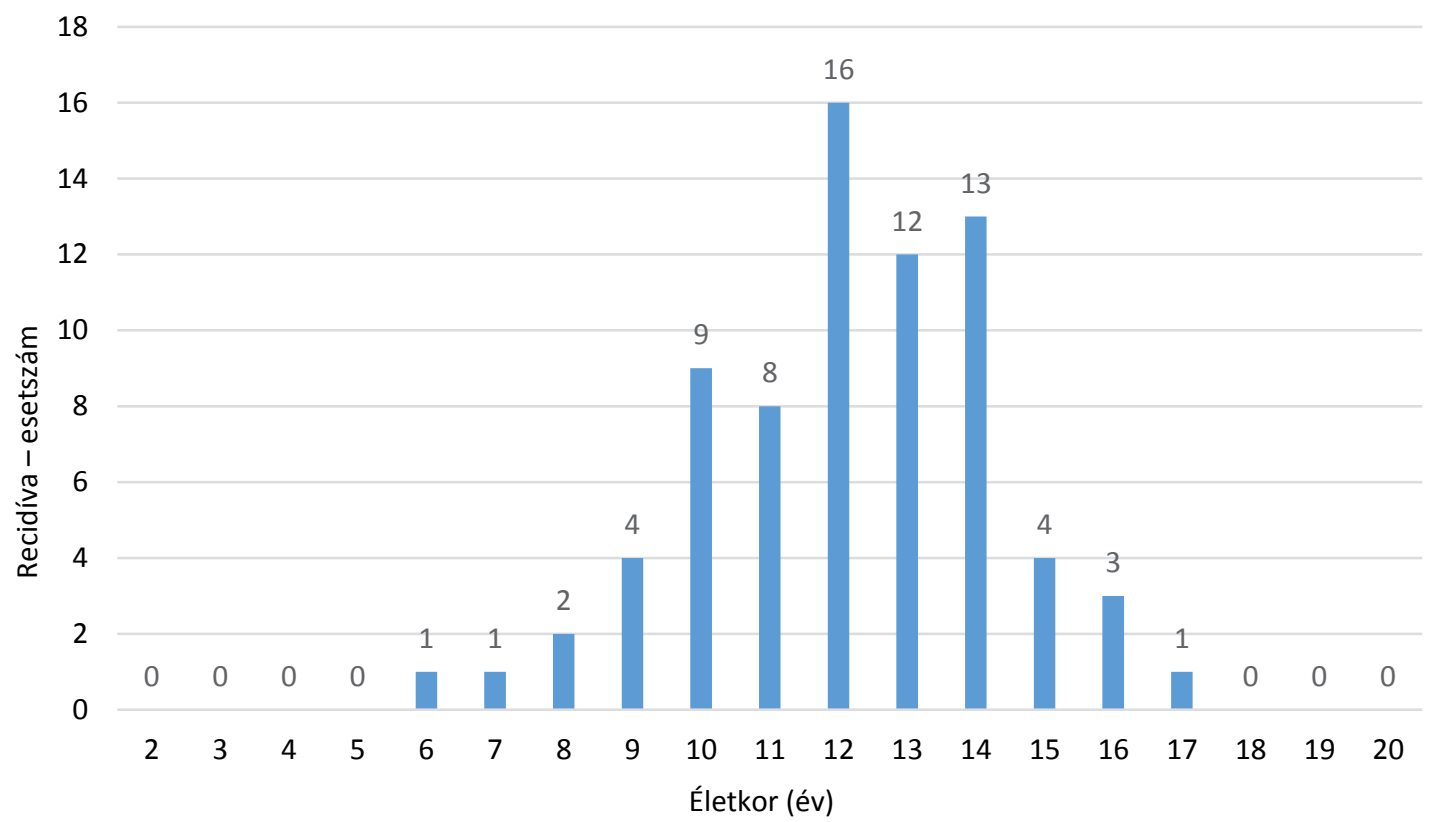

6. ábra

| A recidíva előfordulási aránya az életkornak megfelelően

Mútétet követő túlkorrekciót, úgynevezett calcaneus deformitást és progresszíven romló guggoló járásmintázatot 12 esetben $(3,5 \%)$ láttunk. A túlkorrekciót a Borton által leírt kritériumoknak megfelelően definiáltuk [8]. Az említett szövődmény döntően a nyílt Z-tenotomián átesett betegeket érintette. 4 esetben percutan mútétet követően láttunk túlkorrekciót, mely a percutan mútétek 1,5\%-a volt, ezzel szemben 8 esetben találkoztunk a súlyos komplikációval nyílt mútétet követően, mely az összes nyílt mútét 9,3\%-át jelentette.

A túlkorrekció minden esetben GMFCS II-III. stádiumú, relatíve jó járásképességgel bíró parapareticus betegeknél volt látható. 10 esetben a komplikáció ismételt achillotenotomiát követően jelentkezett.

\section{Megbeszélés}

A mai modern sebészeti gyakorlatban egyre inkább előtérbe kerülnek a minimálinvazív mútéti beavatkozások, melyek fóleg a közvetlen perioperatív időszakban, de hosszabb távon is elónyöket jelentenek a betegek számára. Ezen törekvések érintik az egyik klasszikus ortopédiai beavatkozást, az achillotenotomiát is. Ahogy eredményeinkből is kitúnik, a percutan tripla hemisectio a klinikánkon történt 1990. évi bevezetése óta fokozatosan elótérbe került. Napjainkban már szinte kivétel nélkül ezt a megoldást preferáljuk mind a primer beavatkozásoknál, mind a reoperációkat tekintve. Ahogy eredményeink is mutatják, a hosszabb hospitalizációs időből, a sebgyógyulási zavarokból és a jelentősebb hegképződésből származó komplikációkat a minimálinvazív módszerrel sikerült visszaszorítani.

A funkcionális eredményeket áttekintve láthatjuk, hogy az alkalmazott mútét minden esetben jelentősen javítja a betegek álló- és járóképességét. Tapasztalatunk alapján az equinustartás megszüntetésével, így az álló- és járóképesség javításával a zárt kinematikus láncot képező többi alsó végtagi ízület állapotán is segíthetünk. Az állóképesség kialakításával és az így elért nagyobb terheléssel a csípő́izületben javul a femurfej és az acetabulum kontaktusa, ami elősegítheti az acetabulum és a vápatető megfelelő irányú fejlődését, illetve csökkentheti a collodiaphysealis szög értékét és a femurnyak anteversióját. Hasonlóképpen, a térdízületben létrejövő nyújtóerők álláskor és járáskor elősegíthetik a térdízületi flexiós contractura oldódását is [9].

Hosszú távú eredményeink alapján elmondhatjuk, hogy a leggyakoribb szövődményünk a recidíva volt. Ugyanakkor megemlítendő, hogy a recidíva tulajdonképpen nem valódi szövődmény, hanem a kezelés egyfajta természetes velejárója. Átlagos előfordulási aránya szakirodalmi adatok alapján 20\% (0-43\%) [8-16], mely korrelál adatainkkal. Kialakulásának hátterében számos szerző a természetes testnövekedést véleményezte [1618], ugyanis a megrövidült, spasticus plantarflexorok növekedése feltételezhetóen elmarad az alsó végtag és a csontok hossznövekedésétől. Ezen összefüggést látszanak alátámasztani a mi eredményeink is. Ahogy láthattuk, a fiatalabb korban végzett beavatkozások esetén lényegesen magasabb a recidívaráta $[13,16]$. Hasonlóképpen megfigyeltük, hogy a recidíva pubertáskorban, a gyors testnövekedési fázisban mutat halmozódást [18, 19]. Ezen megfigyelésünk azonban csupán a kronológiai kort vette figyelembe, ugyanis a vizsgált betegeknél az utánkövetés során nem készültek a csontkor meghatározására alkalmas radiológiai képek, melyek megállapításunkat tovább erősítenék. A testnövekedés szerepét tovább erősítik a funkcionális eredmények, ugyanis a 
mútéteket követően jelentős PRS-pontszám-növekedést láttunk, ezt követően pedig hosszú távon lassú, nem szignifikáns csökkenést tapasztaltunk a pontszámokban. Az észlelt összefüggés alapján logikus lenne későbbi életkorra halasztani a mútétet, ennek ellenére javasoljuk fiatalabb korban a mútét elvégzését, hiszen e nélkül sok esetben sem az álló-, sem a járóképesség nem érhető el.

Feltételeztük, hogy az alapbetegség súlyossága összefüggést mutathat a recidíva előfordulásával. Eredményeink igazolni látszanak ezt a feltevést, ugyanis ahogy korábban látható volt, a GMFCS III-IV-es stádiumú betegeknél lényegesen gyakrabban kényszerültünk reoperációra.

Szakirodalmi adatok azt mutatják, hogy az alapbetegség topográfiai megjelenési formái összefüggést mutatnak a recidíva előfordulásával $[8,9,13,16]$. Feltételezik, hogy a hemipareticus betegeknél a legmagasabb a recidíva előfordulási aránya, ugyanis ezek a betegek valamenynyire kímélik az érintett végtagot, így a járás során jótékonyan ható dorsalflexiós feszítőerők nem érvényesülnek. Ezt az összefüggést alátámasztja a hemipareticus betegeknél észlelt 23,9\%-os recidívaráta. Ezzel szemben saját eredményeink alapján a parapareticus betegeknél volt a legmagasabb a recidíva előfordulási aránya, míg a vártakkal ellentétben, négy végtagi érintettségnél volt a legalacsonyabb. Az említett megoszlás magyarázata feltehetően az, hogy a négy végtagi érintettségben szenvedő betegeknél lényegesen alacsonyabb volt a súlyos esetek száma. Tehát a tetrapareticus betegek többségénél az alapbetegség súlyossága a GMFCS II-es stádiumba volt sorolható $(69,5 \%)$, míg a hemi- és parapareticus betegeknél a GMFCS III-IV-es stádiumok domináltak $(66,2 \%)$. Ezen eredmények alapján véleményünk szerint az alapbetegség súlyossága és a spasticitas mértéke erősebben befolyásolja a recidíva előfordulását, mint a cerebralis paresis topográfiai megjelenési formája.

$\mathrm{Az}$ alkalmazott mútéti technikák egyetlen valódi és súlyos szövődménye a túlkorrekció, mely a járásképesség progresszív romlásához vezet, és igen nehezen kezelhető. A túlkorrekció előfordulási aránya szakirodalmi adatok alapján $~ 10 \%(0-36 \%)[8-11,13,14,16,17,19$, 20], mely jól korrelál eredményeinkkel. A szakirodalomban nincs konszenzus a túlkorrekció definícióját illetően. Egyes szerzók az achillotenotomiát követően gyakran látott pes planovalgust is túlkorrekciónak tekintik, míg mások - köztük mi is - a súlyos fokú plantarflexiós elégtelenséget, az úgynevezett calcaneus tartást és a progresszíven romló járásképet tekintjük túlkorrekciónak [21]. Ahogy eredményeinkból kitúnik, a definíciónknak megfelelő túlkorrekcióval többségében nyílt Z-tenotomiát követően találkoztunk. A két mútéti megoldás ilyen irányú különbsége abból adódik, hogy míg tripla hemisectiónál az Achilles-ín nyúlásának mértékét az ín mérete, anatómiai sajátosságai valamilyen szinten korlátozzák, addig nyílt mútét esetén jóval nagyobb nyújtást tudunk elérni, így átléphetjük azt a pontot, ahol a dorsalflexorok és a plantarflexorok egyensúlya megbomlik, és az amúgy is spasticus dorsalflexorok a lábat calcaneus állásba húzzák.

Tapasztalataink azt mutatják, hogy a túlkorrekció leginkább a relatíve jó járásképességgel rendelkező GMFCS II-III-as stádiumú parapareticus betegeket veszélyezteti, különösen ismételt mútét esetén. Ennek oka feltehetően az, hogy ezen - jó járóképességú - betegeknél a járás során erősebb nyújtó erôhatás éri az akár többszörösen is mútétileg megnyújtott és heges Achilles-inat.

\section{Következtetés}

A cerebralis paresisben szenvedő betegeknél kialakuló equinusdeformitás kezelésének egyik legfontosabb komponense a mútéti kezelés. Az utóbbi években a mútéti technikát tekintve klinikánkon előtérbe került a bemutatott minimálinvazív módszer, mely számos előnnyel rendelkezik, és igen kis szövődményrátával bír. Eredményeink azt mutatják, hogy a recidíva a legfontosabb komplikáció, amellyel hosszú távon számolnunk kell. Ennek legfontosabb rizikófaktoraiként a mútéti életkort és az alapbetegség súlyosságát azonosítottuk. Megfigyeltük, hogy a recidíva kialakulása szoros összefüggést mutat a testnövekedéssel: ez alapján előfordulására a leginkább a pubertáskorban számíthatunk, ami miatt javasolt a betegek szoros utánkövetése, egészen a testnövekedés befejeződéséig.

Anyagi támogatás: A szerzők a közlemény megírásához anyagi támogatásban nem részesültek.

Szerzôi munkamegosztás: K. G.: A kutatási terv elkészítése, a forrásdokumentumok összegyújtése, a vizsgálat lefolytatása, a statisztikai elemzés elkészítése, a kézirat megszövegezése, ambuláns betegvizsgálat. F. L.: A vizsgálat lefolytatása, ambuláns betegvizsgálat. Sz. T.: A vizsgálat lefolytatása, ambuláns betegvizsgálat, a statisztikai elemzés elkészítése. T. P.: A hipotézis felállítása, a kutatási terv ellenórzése, a kézirat megszövegezése. V. Cs.: A hipotézis felállítása, a kutatási terv ellenőrzése, ambuláns betegvizsgálat, a kézirat megszövegezése. A cikk végleges változatát valamennyi szerző elolvasta és jóváhagyta.

Érdekeltségek: A szerzőknek nincsenek érdekeltségeik.

\section{Irodalom}

[1] Vízkelety T. Neuromuscular diseases. In: Szendrői M. (ed.) Orthopedics. [Neuromuscularis betegségek. In: Szendröi M. (szerk.) Ortopédia.] Semmelweis Kiadó, Budapest, 2009; pp. 113-117. [Hungarian]

[2] Carmick J. Managing equinus in a child with cerebral palsy: merits of hinged ankle-foot orthoses. Dev Med Child Neurol. 1995; 37: 1006-1010.

[3] Carr LJ, Cosgrove AP, Gringras P, et al. Position paper on the use of botulinum toxin in cerebral palsy. Arch Dis Child. 1998; 79: $271-273$. 
[4] Douté DA, Sponseller PD, Tolo VT, et al. Soleus neurectomy for dynamic ankle equinus in children with cerebral palsy. Am J Orthop. 1997; 26: 613-616.

[5] Corry IS, Cosgrove AP, Duff CM, et al. Botulinum toxin A compared with stretching casts in the treatment of spastic equinus: a randomised prospective trial. J Pediatr Orthop. 1998; 18: 304311.

[6] Terebessy T, Domos G, Hevér D, et al. Botulinum toxin treatment in children with cerebral palsy. [Botulinumtoxin-kezelés infantilis cerebralis paresisben.] Orv Hetil. 2019; 160: 11051111. [Hungarian]

[7] Palisano R, Rosenbaum P, Walter S, et al. Development and reliability of a system to classify gross motor function in children with cerebral palsy. Dev Med Child Neurol. 1997; 39: 214-223.

[8] Borton DC, Walker K, Pirpiris M, et al. Isolated calf lengthening in cerebral palsy. Outcome analysis of risk factors. J Bone Joint Surg Br. 2001; 83: 364-370.

[9] Lofterød B, Terjesen T. Local and distant effects of isolated calf muscle lengthening in children with cerebral palsy and equinus gait. J Child Orthop. 2008; 2: 55-61.

[10] Kay RM, Rethlefsen SA, Ryan JA, et al. Outcome of gastrocnemius recession and tendo-achilles lengthening in ambulatory children with cerebral palsy. J Pediatr Orthop B 2004; 13: 9298.

[11] Damron TA, Greenwald TA, Breed AL. Chronologic outcome of surgical tendoachilles lengthening and natural history of gastrocsoleus contracture in cerebral palsy. A two-part study. Clin Orthop Relat Res. 1994; 301: 249-255.

[12] Banks HH. The management of spastic deformities of the foot and ankle. Clin Orthop Relat Res. 1977; 122: 70-76.

[13] Graham HK, Fixsen JA. Lengthening of the calcaneal tendon in spastic hemiplegia by the White slide technique. A long-term review. J Bone Joint Surg Br. 1988; 70: 472-475.
[14] Lyon R, Liu X, Schwab J, et al. Kinematic and kinetic evaluation of the ankle joint before and after tendo Achilles lengthening in patients with spastic diplegia. J Pediatr Orthop. 2005; 25: 479483.

[15] Sala DA, Grant AD, Kummer FJ. Equinus deformity in cerebral palsy: recurrence after tendo Achillis lengthening. Dev Med Child Neurol. 1997; 39: 45-48.

[16] Rattey TE, Leahey L, Hyndman J, et al. Recurrence after Achilles tendon lengthening in cerebral palsy. J Pediatr Orthop. 1993; 13: 184-187.

[17] Truscelli D, Lespargot A, Tardieu G. Variation in the long-term results of elongation of the tendo Achillis in children with cerebral palsy. J Bone Joint Surg Br. 1979; 61: 466-469.

[18] Joo SY, Knowtharapu DN, Rogers KJ, et al. Recurrence after surgery for equinus foot deformity in children with cerebral palsy: assessment of predisposing factors for recurrence in a longterm follow-up study. J Child Orthop. 2011; 5: 289-296.

[19] Sharrard WJ, Bernstein S. Equinus deformity in cerebral palsy. A comparison between elongation of the tendo calcaneus and gastrocnemius recession. J Bone Joint Surg Br. 1972; 54: 272 276.

[20] Dietz FR, Albright JC, Dolan L. Medium-term follow-up of Achilles tendon lengthening in the treatment of ankle equinus in cerebral palsy. Iowa Orthop J. 2006; 26: 27-32.

[21] Shore BJ, White N, Kerr-Graham H. Surgical correction of equinus deformity in children with cerebral palsy: a systematic review. J Child Orthop. 2010; 4: 277-290.

(Kérő Gábor dr., Pécs, Akác u. 1., 7632 e-mail: kero.gabor@pte.hu)

\section{„Solet esse in dubiis pro consilio temeritas." (Válságban a merészség pótolja a megfontoltságot.)}

A cikk a Creative Commons Attribution 4.0 International License (https://creativecommons.org/licenses/by/4.0/) feltételei szerint publikált Open Access közlemény, melynek szellemében a cikk bármilyen médiumban szabadon felhasználható, megosztható és újraközölhető, feltéve, hogy az eredeti szerző és a közlés helye, illetve a CC License linkje és az esetlegesen végrehajtott módosítások feltüntetésre kerülnek. (SID_1) 